\title{
Recent Update: Effects of Aflatoxin in Broiler Chickens
}

\author{
Kurniasih $^{1}$ and Yos Adi Prakoso ${ }^{2 *}$ \\ ${ }^{I}$ Department of Pathology, Faculty of Veterinary Medicine, University of Gadjah Mada, Indonesia \\ ${ }^{2}$ Faculty of Veterinary Medicine, University of Wijaya Kusuma Surabaya, East Java, Indonesia
}

*Corresponding author's Email: yos.vet.docter@gmail.com; ORCID: 0000-0003-4908-6661

Received: 25 Apr. 2019

Accepted: 23 May. 2019

\begin{abstract}
Aflatoxin is a worldwide problem in poultry industries as it is known to contaminate poultry feed. Aflatoxin induces stress and increases mortality rate during infection in poultry, especially broiler chickens. The objectives of this study was to observe the pathological effects due to aflatoxicosis in broiler chickens. A total of 120 chickens were divided into four groups, group A fed with a basal diet without aflatoxin contamination, group B with aflatoxin $(>1 \mathrm{ppb}<50 \mathrm{ppb}$ ), group $\mathrm{C}$ with aflatoxin ( $>51 \mathrm{ppb}<100 \mathrm{ppb}$ ), group D with aflatoxin $(>101 \mathrm{ppb}<$ $150 \mathrm{ppb}$ ). The data were collected and analysed on day 7, 14, and 21 . The results showed that diet with high aflatoxin contamination in group D impaired the physical and laboratory performances of the chickens, increased the risk of residue in the poultry's final products. The varying doses of aflatoxin contamination in the chicken feed causes the problems on the broiler chickens with different level of severity.
\end{abstract}

Key words: Aflatoxin, Antibody, Broiler, Haematology, Immunohistochemistry, Residue

\section{INTRODUCTION}

Aflatoxin is the most prevalent mycotoxin synthesised by Aspergillus flavus, Aspergillus parasiticus, and Aspergillus nomius in the ideal temperature and humidity (Morrison et al., 2017). Prolonged storage of the chicken's feed creates a high synthesis of the aflatoxin (Sarma et al., 2017). Aflatoxin induces severe cellular defects and carcinogenesis (Kim et al., 2016). The disease is caused by aflatoxin known as aflatoxicosis (Wogan et al., 2012). The prevalence of aflatoxicosis is not limited to some limited geographical area. The clinical manifestations of aflatoxicosis are lethargy, anorexia, lower growth rate, microbial stress, economic losses and toxicity (Sarma et al., 2017). The aflatoxin found as a residue on the poultry's final product (Denli et al., 2009), and it represents the port of entry of aflatoxin exposure in human (Manafi et al., 2014).

Mostly, the previous study has shown the effects of a single type of aflatoxin such as Aflatoxin B1 (AFB1) (Bintvihok and Kositcharoenkul, 2006). AFB1 is commonly reported because it has the highest toxicity (Mughal et al., 2017). However, poultry aflatoxicosis naturally is caused by several types of toxins, unlimited to AFB1 and it may be with varying doses. Both of doses (low and high) and types of aflatoxin exposes to human and animal can causes several impacts (Qureshi et al., 2015). The differing types and amount of synthesised aflatoxin in one sample have defined as the total aflatoxin (Kamala et al., 2018). It is necessary to explore profoundly toward the impacts of the aflatoxin contamination in the poultry. This study aimed to explore the impacts of natural contamination of aflatoxin in the chicken's feed.

\section{MATERIALS AND METHODS}

\section{Ethical approval}

This study was approved by the ethical clearance committee of the faculty of veterinary medicine, university of Gadjah Mada, with license number 0010 / EC - FKH / Int / 2017.

\section{Experimental animals and design}

The experiment was performed in the integrated laboratory, faculty of health, the university of Muhammadiyah Sidoarjo from November 2017 until April 2018. All the experimental procedure followed the federal guidelines for the care and use of laboratory animal. 120 of one-day-old chickens of broiler strain Cobbwere randomly divided into four groups. Group A was control 
group that fed a diet with aflatoxin undetectable, group B was fed a diet naturally contaminated with aflatoxin $(>1$ $\mathrm{ppb}<50 \mathrm{ppb}$ ), group $\mathrm{C}$ with aflatoxin $(>51 \mathrm{ppb}<100$ $\mathrm{ppb})$ and group $\mathrm{D}$ with aflatoxin (> $101 \mathrm{ppb}<150 \mathrm{ppb}$ ). The chickens were treated in 24 hours light schedule with decreasing of its intensity after 16 hours per day, $30{ }^{\circ} \mathrm{C}$ temperature, and $65 \%$ humidity for 21 days. The water and feed were given ad libitum. The chickens were vaccinated by Newcastle Disease (ND) and Infectious Bursal Disease (IBD) vaccine on day three, and Avian Influenza (AI) vaccine on day five.

\section{Diet}

The chickens were fed with a broiler starter diet contained $23 \%$ of crude protein and $3200 \mathrm{kcal}$ metabolizable energy. The total aflatoxin of chicken feed was routinely tested by Enzyme-Linked Immunosorbent Assays (ELISA). The chicken feed was incubated based on the following method that was indicated by the previous study (Prakoso et al., 2018). The total aflatoxin was measured each day during the study with a triple of replication. The observation results of aflatoxin levels are reported in table 1 .

Table 1. Total aflatoxin level (ppb) of feed of broiler chickens from day 1 until day 21

\begin{tabular}{|c|c|c|c|c|}
\hline Day Groups & $\mathbf{A}$ & B & C & D \\
\hline 1 & 0 & 22.57 & 74.85 & 120.56 \\
\hline 2 & 0 & 49.96 & 79.21 & 137.84 \\
\hline 3 & 0 & 28.15 & 94.56 & 141.25 \\
\hline 4 & 0 & 36.22 & 78.55 & 149.03 \\
\hline 5 & 0 & 36.36 & 90.04 & 115.94 \\
\hline 6 & 0 & 29.45 & 88.48 & 140.18 \\
\hline 7 & 0 & 46.81 & 94.23 & 139.44 \\
\hline 8 & 0 & 40.52 & 80.00 & 135.21 \\
\hline 9 & 0 & 28.19 & 68.29 & 128.68 \\
\hline 10 & 0 & 25.44 & 78.86 & 130.65 \\
\hline 11 & 0 & 28.91 & 95.52 & 140.78 \\
\hline 12 & 0 & 30.15 & 89.01 & 145.24 \\
\hline 13 & 0 & 33.47 & 96.66 & 136.22 \\
\hline 14 & 0 & 38.32 & 77.18 & 144.68 \\
\hline 15 & 0 & 29.01 & 86.25 & 133.00 \\
\hline 16 & 0 & 40.11 & 79.18 & 148.07 \\
\hline 17 & 0 & 43.78 & 90.09 & 136.88 \\
\hline 18 & 0 & 39.18 & 88.87 & 140.15 \\
\hline 19 & 0 & 44.83 & 89.21 & 129.38 \\
\hline 20 & 0 & 44.05 & 90.03 & 148.55 \\
\hline 21 & 0 & 47.18 & 93.05 & 140.00 \\
\hline Mean \pm SD & 0 & $36.32 \pm 8.02$ & $85.81 \pm 7.83$ & $137.22 \pm 8.64$ \\
\hline
\end{tabular}

$\mathrm{SD}=$ standard of deviation.
Body weight, feed intake and feed conversion rate

The chickens were weighed using the body weight scale on day 7, 14 and 21 during the treatments. Following the weight recording, the chicken's FI and FCR were measured using the formulae, FCR = feed intake (g)/ body weight $(\mathrm{g})$.

\section{Sample collection}

10 chickens from each group were euthanised by cervical replacement on day 7,14 and 21. The chicken's body weight was measured, and the blood and serum samples were collected before the euthanasia. The liver, kidney, spleen, Bursa of Fabricius (BF) and thymus were weighed using scale and expressed as the Relative Organ Weight (ROW). It was measured using the formulae, ROW $=$ organ weight $(\mathrm{g}) /$ body weight $(100 \mathrm{~g})$. After the measurement, those organs were divided into two part. The first parts were stored in the sterile plastic and saved in the refrigerator for ELISA test against total aflatoxin. The second parts were stored in $10 \%$ neutral buffer formalin for immuno-histopathological examination.

\section{Histopathology and immunohistochemistry}

The broiler chicken's organs (liver, kidney, spleen, $\mathrm{BF}$ and thymus) were dehydrated using the graded ethanol and xylene, embedded and blocked in the liquid paraffin. The tissue samples were prepared into $5 \mu \mathrm{m}$ diameter with duplication. The first sections were mounted on the glass slide for histopathology. The second section of spleen, BF and thymus were mounted on the slide coated with polylysine for immunohistochemistry. The histopathology was performed using the Hematoxylin and Eosin (H\&E) staining and immunohistochemistry was done using antibody anti-CD3+, CD4+, and CD8+. The morphometry of H\&E staining was performed for the organs of broiler chickens on day 7, 14, and 21 by a single pathologist. All the observed histopathological changes were reported. The immunohistochemical slides of the broiler chicken's organs were analysed on day 21 using the scoring system from 0 to 4 as follow: absence $=0$, minimal $=1$, ild $=2$, moderate $=3$ and severe $=4$.

Haematological, heterophil phagocytic activity, average phagocytic bacteria, and phagocytic index

The blood samples were analysed by the routine haematological test following the standard laboratory procedure. The blood parameters contained erythrocytes total/ Red Blood Cells (RBC), Packed Cells Volume (PCV), Haemoglobin (Hb), Mean Corpuscular Volume (MCV), Mean Corpuscular Haemoglobin (MCH), Mean 
Corpuscular Haemoglobin Concentration (MCHC), leucocytes total/ White Blood Cells (WBC) and differential count of leucocytes. The Heterophil Phagocytic Activity (HPA) against Staphylococcus aureus (ATCC® BAA-1690) was measured and analysed following the previous study (Sornplang et al., 2015). The Phagocytic Index (PI) was measured using the formula, PI $=$ [percentage of heterophils containing bacteria $) \times($ the Average number of Phagocytic Bacteria (APB) per ingesting heterophils] $\times 100$.

\section{Titre antibody measurement}

The serum samples are tested by Haemagglutination Inhibition (HI) test against titre antibody of ND, IB, and AI following the standard procedure. The HI test results reported as the Geometric Mean Titre (GMT).

\section{Enzyme-linked immunosorbent assays}

The ELISA test was performed to analyse the residue of aflatoxin level in the broiler chicken's organ (liver, kidney, spleen, BF, thymus, skin and muscle). The organ samples were weighed and about $2 \mathrm{gr}$, extracted, centrifuged then the aliquots reacted with peroxidase conjugate and antibody solution against aflatoxin. The samples were incubated for 30 minutes, washed, and added the stop reagent to end the further reaction. The absorbance was measured with ELISA reader using 450 $\mathrm{nm}$ wavelength using the standard curve.

\section{Data analysis}

The data of the chicken body weight, FI, FCR, the relative weight of the organ, haematology, HPA, APB, PI, GMT, immunohistochemistry and aflatoxin residue were analysed by SPSS (version 16) using two-way ANOVA and post hoc tests in significance level of 0.05 . However, the histopathological data were analysed by using Kruskal - Wallis and Mann Whitney U tests.

\section{RESULTS AND DISCUSSION}

The results showed that contamination of the aflatoxin in the chicken's feed affected the muscle mass formation. It is approved by the significantly different regarding chicken's body weight $(\mathrm{P}<0.05)$. Those effects are caused by decreasing of FI in chickens of the group D that treated with high aflatoxins $(\mathrm{P}<0.05)$. FI is an indicator of the broiler industry used to determine the chicken's productivity. Commonly, the FI of the broiler chicken is increasing when the broiler has treated in suitable milieu including the humidity, temperature and feeds. In this case, the decrease of FI was promoted by stress and immune-depression of broiler during aflatoxin exposure. Moreover, it can be elucidated using the FCR as a further indicator. The highest FCR was indicated in group D $(\mathrm{P}<0.05)$ compared to the other groups. This finding approved that aflatoxin has impaired the chicken's metabolism through the disturbance of gut and liver activity (Zuidhof et al., 2014). It is supported by the significant gross histopathological changes of liver, kidney, spleen, $\mathrm{BF}$, and thymus in group $\mathrm{C}$ and $\mathrm{D}$ with high exposure doses of aflatoxin $(\mathrm{P}<0.05)($ Table 2$)$.

Gross pathological change on the visceral organ decreases cellular absorption and metabolism. Aflatoxin increases the relative weight of the liver and kidney due to the cellular defect. The liver has a role in detoxification and kidney in filtration and excretion (Matur et al., 2010). Every secondary metabolite of toxins was metabolised in the liver and stored in its cytoplasm. The aflatoxin impairs the equilibrium of the endogenous antioxidant in the cellular biological system and causes the increasing level of the oxidative stress (Yaman et al., 2016).

The oxidative stress accumulates in the hepatocytes,induce inflammation and cellular necrosis (Baptista et al., 2008). Those cellular effects are shown by liver enlargement macroscopically. The increase of liver relative weight in present study is supported by the histopathological finding which had been shown the severe inflammation in both perilobular and interlobular area, degeneration and bile duct proliferation $(\mathrm{P}<0.05)$ (Table 3). The liver hepatocytes play an essential role in the detoxification of the toxin and xenobiotics (Colakoglu and Donmez, 2012). High accumulation of the toxin promotes the degeneration (Figure 1a) that is induced by the oxidative stress and impairment of cellular metabolism (Guo et al., 2013). Chronic oxidative stress is aggravated by prolonged inflammation in the liver (Figure 1b), and it caused severe necrosis (Figure 1c). The bile duct is proliferating as the compensatory effects during toxin excretion from the liver (Figure 1d). Those histopathological changes are observed massively in group D (Figure 1a-1d).

The similar consequences due to aflatoxicosis are illustrated by the histopathological finding in the kidney $(\mathrm{P}<0.05)$ (Table 3$)$. As the main excretory organ, the kidney plays an essential role in filtering blood and removing waste products. In this study, the imbalance of kidney function is demonstrated in both macroscopic and microscopical examination. Further, the tubular degeneration is observed on the group treated with high aflatoxin contamination (Figure 2a). 
Table 2. The effects of aflatoxin exposure on the broiler chicken's body weight, feed intake, feed conversion rate and relative weight of the organs at day 7,14 and 21

\begin{tabular}{|c|c|c|c|c|c|c|}
\hline \multicolumn{2}{|c|}{ Parameters } & $\begin{array}{c}\text { Day } \\
7\end{array}$ & \multicolumn{4}{|c|}{ Groups } \\
\hline \multicolumn{2}{|c|}{ Body weight (g) } & 14 & $338.09 \pm 10.89^{\mathrm{a}}$ & $333.85 \pm 5.03^{\mathrm{a}}$ & $328.74 \pm 7.46^{\mathrm{a}}$ & $317.50 \pm 8.33^{b}$ \\
\hline \multirow{2}{*}{\multicolumn{2}{|c|}{ Feed intake (gram) }} & 14 & $567.90 \pm 5.19^{\mathrm{a}}$ & $560.50 \pm 7.21^{\mathrm{a}}$ & $555.60 \pm 5.77^{\mathrm{a}}$ & $548.10 \pm 9.19^{b}$ \\
\hline & & 21 & $1228.37 \pm 10.28^{\mathrm{a}}$ & $1219.70 \pm 16.64^{\mathrm{a}}$ & $1221.23 \pm 18.07^{\mathrm{a}}$ & $1204.50 \pm 20.56^{\mathrm{b}}$ \\
\hline \multicolumn{2}{|c|}{ Feed conversion rate } & 7 & $1.46 \pm 0.03^{\mathrm{a}}$ & $1.42 \pm 0.01^{\mathrm{a}}$ & $1.43 \pm 0.02^{\mathrm{a}}$ & $1.42 \pm 0.04^{b}$ \\
\hline \multirow{11}{*}{ 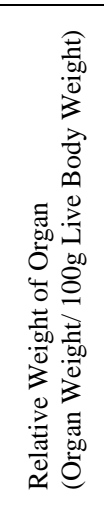 } & \multirow{3}{*}{ Liver } & 7 & $2.28 \pm 0.15^{\mathrm{a}}$ & $2.29 \pm 0.14^{\mathrm{a}}$ & $2.34 \pm 0.11^{\mathrm{a}}$ & $2.60 \pm 0.34^{b}$ \\
\hline & & 14 & $2.26 \pm 0.12^{\mathrm{a}}$ & $2.25 \pm 0.15^{\mathrm{a}}$ & $2.30 \pm 0.13^{\mathrm{a}}$ & $2.45 \pm 0.17^{b}$ \\
\hline & & 21 & $2.34 \pm 0.15^{\mathrm{a}}$ & $2.37 \pm 0.17^{\mathrm{a}}$ & $2.42 \pm 0.10^{\mathrm{a}}$ & $2.53 \pm 0.10^{\mathrm{b}}$ \\
\hline & \multirow{3}{*}{ Kidney } & 7 & $0.62 \pm 0.03^{\mathrm{a}}$ & $0.64 \pm 0.05^{\mathrm{a}}$ & $0.73 \pm 0.04^{b}$ & $0.78 \pm 0.03^{\mathrm{c}}$ \\
\hline & & 14 & $0.60 \pm 0.03^{\mathrm{a}}$ & $0.60 \pm 0.03^{\mathrm{a}}$ & $0.70 \pm 0.03^{b}$ & $0.79 \pm 0.05^{\mathrm{c}}$ \\
\hline & & 21 & $0.61 \pm 0.04^{\mathrm{a}}$ & $0.62 \pm 0.04^{\mathrm{a}}$ & $0.79 \pm 0.03^{b}$ & $0.81 \pm 0.02^{\mathrm{c}}$ \\
\hline & \multirow[t]{2}{*}{ Bursa of Fabricius } & 14 & $0.23 \pm 0.01^{\mathrm{a}}$ & $0.23 \pm 0.01^{\mathrm{a}}$ & $0.22 \pm 0.01^{\mathrm{a}}$ & $0.22 \pm 0.02^{b}$ \\
\hline & & 21 & $0.25 \pm 0.02^{\mathrm{a}}$ & $0.23 \pm 0.01^{\mathrm{a}}$ & $0.23 \pm 0.01^{\mathrm{a}}$ & $0.21 \pm 0.01^{\mathrm{b}}$ \\
\hline & \multirow{3}{*}{ Thymus } & 7 & $0.27 \pm 0.01^{\mathrm{a}}$ & $0.26 \pm 0^{\mathrm{b}}$ & $0.25 \pm 0.01^{\mathrm{b}}$ & $0.23 \pm 0.01^{\mathrm{c}}$ \\
\hline & & 14 & $0.27 \pm 0.02^{\mathrm{a}}$ & $0.26 \pm 0.01^{\mathrm{b}}$ & $0.24 \pm 0.01^{b}$ & $0.23 \pm 0.03^{\mathrm{c}}$ \\
\hline & & 21 & $0.26 \pm 0.02^{\mathrm{a}}$ & $0.26 \pm 0.02^{\mathrm{b}}$ & $0.25 \pm 0.01^{\mathrm{b}}$ & $0.22 \pm 0.01^{\mathrm{c}}$ \\
\hline
\end{tabular}

Table 3. The effects of aflatoxin exposure on the histopathological change of broiler chicken's organs

\begin{tabular}{|c|c|c|c|c|c|c|}
\hline \multirow{2}{*}{ Organs } & \multirow{2}{*}{ Histopathological Change } & \multirow{2}{*}{ Day } & \multicolumn{4}{|c|}{ Groups } \\
\hline & & & $\mathbf{A}$ & B & $\mathbf{C}$ & D \\
\hline \multirow{11}{*}{ Liver } & Necrosis & 14 & $0 / 10^{\mathrm{a}}$ & $1 / 10^{\mathrm{a}}$ & $4 / 10^{\mathrm{b}}$ & $6 / 10^{c}$ \\
\hline & \multirow{3}{*}{ Fatty degeneration } & 7 & $2 / 10^{\mathrm{a}}$ & $2 / 10^{\mathrm{a}}$ & $3 / 10^{\mathrm{b}}$ & $3 / 10^{c}$ \\
\hline & & 14 & $0 / 10^{\mathrm{a}}$ & $1 / 10^{\mathrm{a}}$ & $6 / 10^{\mathrm{b}}$ & $10 / 10^{\mathrm{c}}$ \\
\hline & & 21 & $2 / 10^{\mathrm{a}}$ & $1 / 10^{\mathrm{a}}$ & $8 / 10^{\mathrm{b}}$ & $10 / 10^{\mathrm{c}}$ \\
\hline & Hydropic degeneration & 7 & $0 / 10^{\mathrm{a}}$ & $0 / 10^{\mathrm{a}}$ & $0 / 10^{\mathrm{a}}$ & $1 / 10^{\mathrm{a}}$ \\
\hline & \multirow{3}{*}{ Perilobular inflammation } & 7 & $0 / 10^{\mathrm{a}}$ & $0 / 10^{\mathrm{a}}$ & $1 / 10^{b}$ & $2 / 10^{c}$ \\
\hline & & 14 & $0 / 10^{\mathrm{a}}$ & $1 / 10^{\mathrm{a}}$ & $3 / 10^{\mathrm{b}}$ & $4 / 10^{c}$ \\
\hline & & 21 & $2 / 10^{\mathrm{a}}$ & $1 / 10^{\mathrm{a}}$ & $3 / 10^{\mathrm{b}}$ & $8 / 10^{\mathrm{c}}$ \\
\hline & \multirow{3}{*}{ Interlobular inflammation } & 7 & $1 / 10^{\mathrm{a}}$ & $1 / 10^{\mathrm{a}}$ & $2 / 10^{\mathrm{b}}$ & $3 / 10^{c}$ \\
\hline & & 14 & $0 / 10^{\mathrm{a}}$ & $1 / 10^{\mathrm{a}}$ & $2 / 10^{\mathrm{b}}$ & $7 / 10^{\mathrm{c}}$ \\
\hline & & 21 & $2 / 10^{\mathrm{a}}$ & $1 / 10^{\mathrm{a}}$ & $3 / 10^{\mathrm{b}}$ & $6 / 10^{\mathrm{c}}$ \\
\hline \multirow{5}{*}{ Kidney } & \multirow[t]{2}{*}{ Tubular degeneration } & 14 & $0 / 10^{\mathrm{a}}$ & $2 / 10^{\mathrm{a}}$ & $2 / 10^{\mathrm{a}}$ & $2 / 10^{\mathrm{b}}$ \\
\hline & & 21 & $1 / 10^{\mathrm{a}}$ & $2 / 10^{\mathrm{a}}$ & $1 / 10^{\mathrm{a}}$ & $6 / 10^{\mathrm{b}}$ \\
\hline & \multirow{3}{*}{ Inflammation } & 7 & $0 / 10^{\mathrm{a}}$ & $0 / 10^{\mathrm{a}}$ & $0 / 10^{\mathrm{a}}$ & $3 / 10^{b}$ \\
\hline & & 14 & $0 / 10^{\mathrm{a}}$ & $2 / 10^{\mathrm{a}}$ & $2 / 10^{\mathrm{a}}$ & $3 / 10^{\mathrm{b}}$ \\
\hline & & 21 & $0 / 10^{\mathrm{a}}$ & $0 / 20^{\mathrm{a}}$ & $4 / 10^{\mathrm{a}}$ & $5 / 10^{\mathrm{b}}$ \\
\hline \multirow{3}{*}{ Spleen } & \multirow{3}{*}{ Lymphoid depletion } & 7 & $0 / 10^{\mathrm{a}}$ & $0 / 10^{\mathrm{a}}$ & $2 / 10^{\mathrm{b}}$ & $3 / 10^{c}$ \\
\hline & & 14 & $0 / 10^{\mathrm{a}}$ & $2 / 10^{\mathrm{a}}$ & $3 / 10^{\mathrm{b}}$ & $4 / 10^{c}$ \\
\hline & & 21 & $2 / 10^{\mathrm{a}}$ & $1 / 10^{\mathrm{a}}$ & $3 / 10^{\mathrm{b}}$ & $8 / 10^{c}$ \\
\hline \multirow{3}{*}{$\begin{array}{l}\text { Bursa of } \\
\text { Fabricius }\end{array}$} & \multirow{3}{*}{ Lymphoid depletion } & 7 & $1 / 10^{\mathrm{a}}$ & $2 / 10^{\mathrm{a}}$ & $2 / 10^{\mathrm{a}}$ & $5 / 10^{b}$ \\
\hline & & 14 & $2 / 10^{\mathrm{a}}$ & $1 / 10^{\mathrm{a}}$ & $4 / 10^{\mathrm{a}}$ & $9 / 10^{b}$ \\
\hline & & 21 & $2 / 10^{\mathrm{a}}$ & $3 / 10^{\mathrm{a}}$ & $3 / 10^{\mathrm{a}}$ & $10 / 10^{\mathrm{b}}$ \\
\hline \multirow[b]{2}{*}{ Thymus } & \multirow[b]{2}{*}{ Cortical depletion } & 7 & $0 / 10^{\mathrm{a}}$ & $0 / 10^{\mathrm{a}}$ & $2 / 10^{\mathrm{b}}$ & $2 / 10^{c}$ \\
\hline & & 14 & $0 / 10^{\mathrm{a}}$ & $2 / 10^{\mathrm{a}}$ & $4 / 10^{\mathrm{b}}$ & $4 / 10^{\mathrm{c}}$ \\
\hline
\end{tabular}

\footnotetext{
$\overline{a, b, c}$ the different superscript on the same row showed significantly different values $(\mathrm{P}<0.05)$.
} 
A

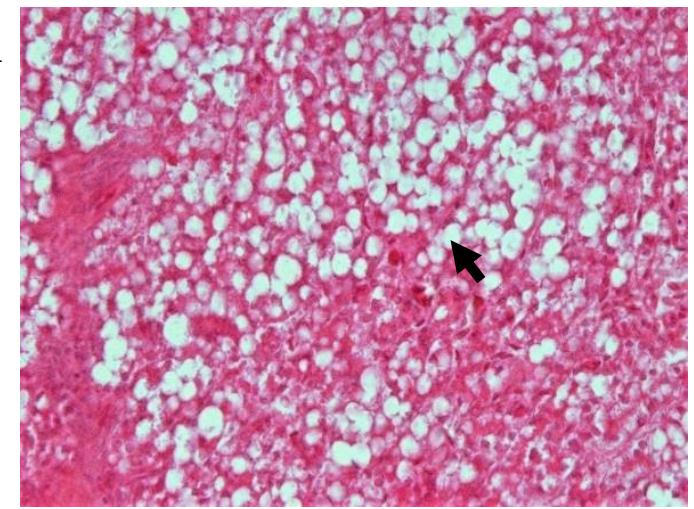

C

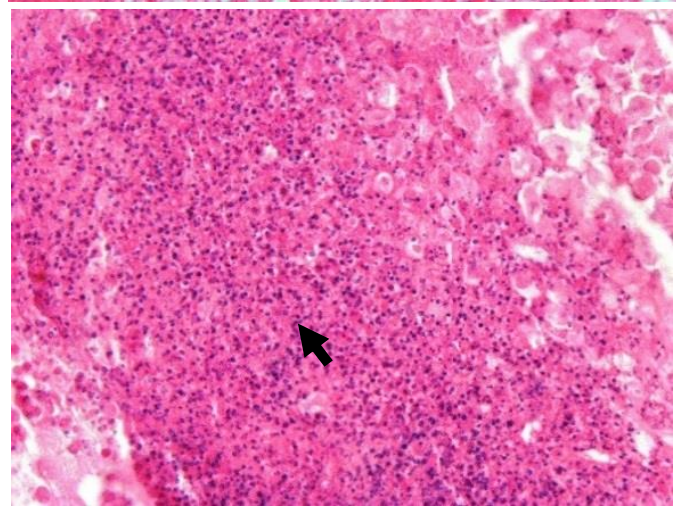

B

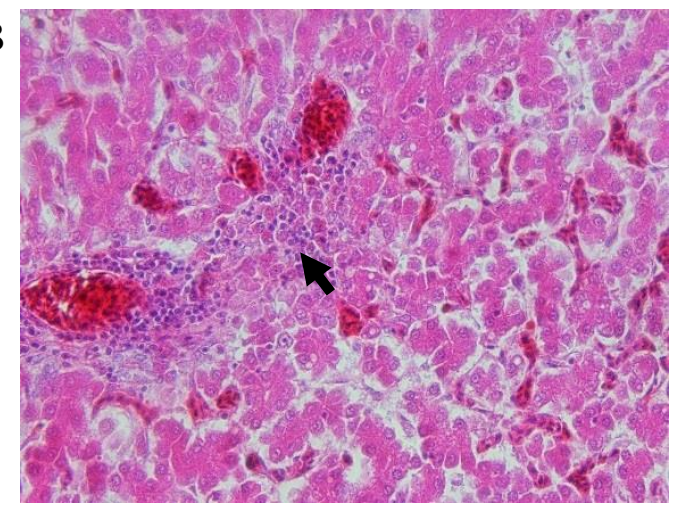

D

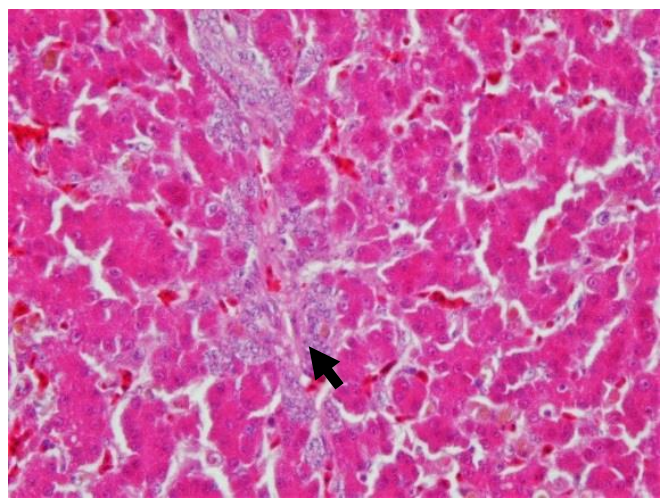

Figure 1. Effects of the aflatoxin on liver histopathology of the broiler chickens. Fatty degeneration (A), lymphocytic inflammation (B), severe necrosis $(\mathbf{C})$, and bile duct proliferation $(\mathbf{D})$ of the liver due to the high exposure of aflatoxin ( $>101 \mathrm{ppb}<150 \mathrm{ppb}$ ) in on day 21 . All histopathological changes are marked by the arrow. H\&E, 100× (A, C), 1000× (B, D).
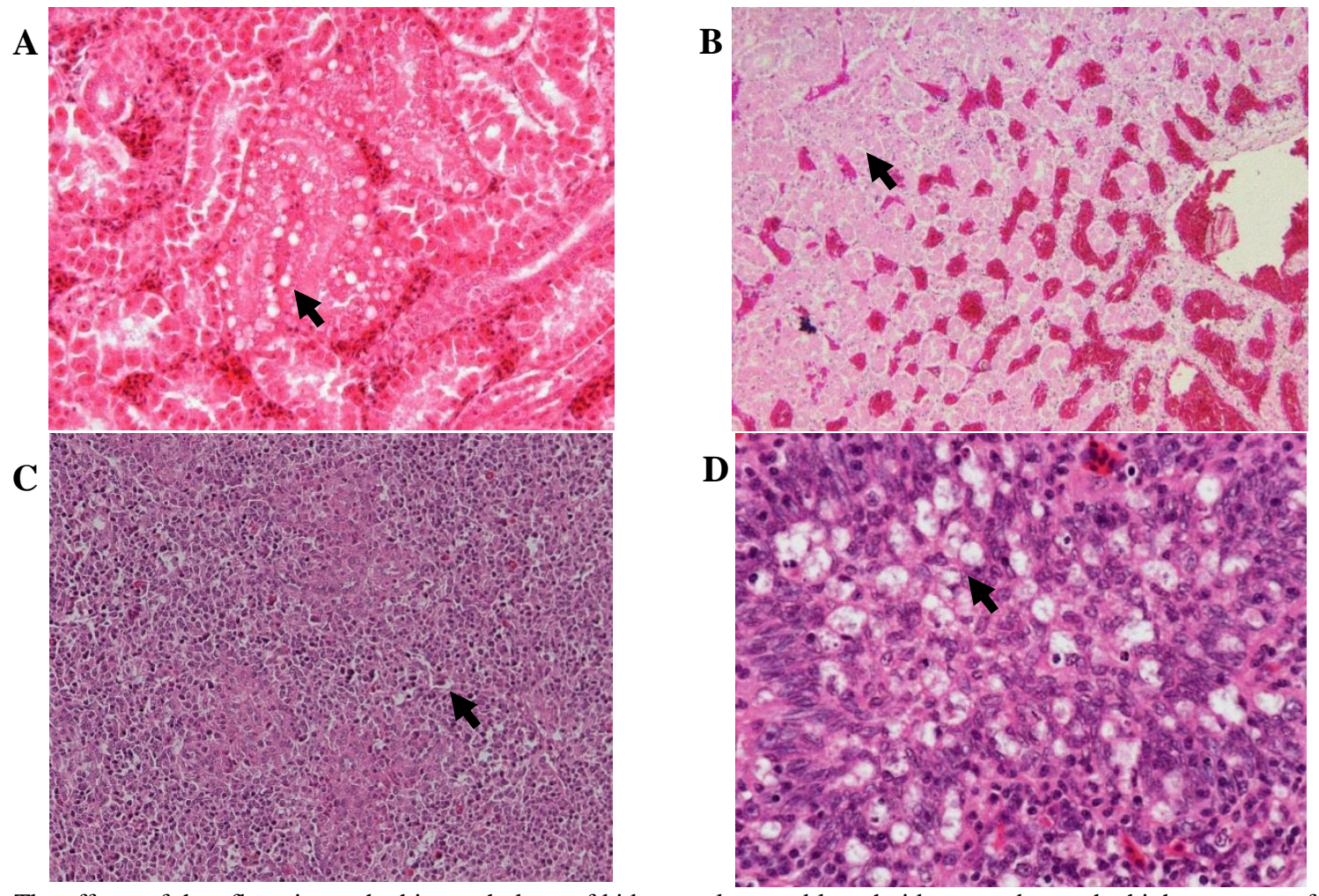

Figure 2. The effects of the aflatoxin on the histopathology of kidney, spleen and lymphoid organ due to the high exposure of aflatoxin (> $101 \mathrm{ppb}<150 \mathrm{ppb}$ ) in broiler chickens on day 21 of experiment. Tubular degeneration with congestion (A), congestion and tubular necrosis (B) of the kidney; white pulp depletion $(\mathbf{C})$ and lymphoid depletion (D) of spleen and bursa of Fabricius. All histopathological changes are marked by the arrow. H\&E, $100 \times(A), 10 \times(B), 4 \times(C)$ and $1000 \times(D)$. 
Those effects were caused by the chaos of exchange of sodium pump in the renal tubule that generates water and sodium retention. Renal cells swelling induces tubular occlusion and decrease the excretory function of the kidney (Liang et al., 2015). Further exploration in the kidney revealed that severe degeneration was followed by tubular necrosis and congestion (Figure 2b). These phenomena are causing the accumulation of aflatoxin in the plasma that gradually aggravates the lesion to another organ (Tokonami et al., 2013).

Aflatoxin significantly affected the relative weight of the lymphoid organ of broiler chickens, especially in group $\mathrm{D}(\mathrm{P}<0.05)$ (Table 2). It is supported by the depletion of lymphoid tissue in spleen and BF (Figure 2c and $2 \mathrm{~d}$ ). Moreover, the vacuolisation observed in the cortical area of the thymus $(\mathrm{P}<0.05)$ (Table 3$)$. The secondary metabolite of aflatoxin accumulates inside the splenocytes, bursal cells and thymocytes that induces the cellular defects (Peng et al., 2015). This accumulation causes the apoptosis of the immune cells, and impair the antibody synthesis. As the base of immune cells proliferation, the lymphoid organ is used as the indicator of immunity in the vertebrates. The immunohistochemistry showed that the decreasing immune expression of CD3+, $\mathrm{CD} 4+$, and CD8+ occur synergistically with aflatoxin exposure level $(\mathrm{P}<0.05)$ (Table 4). CD3+, CD4+, and $\mathrm{CD} 8+$ are the molecular surface of the $\mathrm{T}$ cells subset. $\mathrm{CD} 3+$ is the prominent $\mathrm{T}$ cell produces the antibody clone with high reactivity (Nagel et al., 2014). CD4+ and CD8+ potentially play as cell-mediated immunity during the antibody synthesis and support to destruct the infected cells (Kempashi et al., 2017). The shrinkage of T cells subset in the lymphoid tissue dramatically changes the circulatory phenomenon not only in the haematological aspects but also the antibody synthesis (Yang et al., 2018).

The haematology results obtained that high exposure of aflatoxin causes the severe non-regenerative anaemia indicated by the decreasing number of RBC, PCV, and $\mathrm{Hb}$ $(\mathrm{P}<0.05)$, without increasing of MCV. No statistical differences were observed regarding the MCV, $\mathrm{MCH}$ and MCHC in all groups $(\mathrm{P}>0.05)$ (Table 5). Further, the lymphocytes are significantly decreased in both group $\mathrm{C}$ and $\mathrm{D}$ that indicated a low synthesis of antibody $(\mathrm{P}>0.05)$. This result is supported by the previous study that aflatoxin was able to change haematology and biochemistry parameters before the developing of the clinical signs (Tessari et al., 2010; Mahfouz and Sherif, 2015). In this study, the aflatoxin induced normocytic normochromic anaemia due to the inhibition of protein synthesis. However, lymphocytopenia was caused by dramatical increasing of apoptosis in the lymphoid organs that inhibit the proliferation and maturation of the circulatory lymphocytes (Donmez et al., 2012). Chronic inflammation and severe cellular necrosis play as the chemo-attractant in monocyte infiltration. Further, it induces monocytosis. Monocyte is the phagocytic mononuclear cells to destroy and recycle tissue debris. The monocytes infiltration in the aflatoxicosis induces external trap formation of macrophages (An et al., 2017).

Present study proved that the aflatoxin inhibited the numbers of circulatory heterophil and its phagocytic activity $(\mathrm{P}<0.05)$ (Table 6). The phagocytosis is the first lineage of a defensive strategy against the pathogenic agents in the animal including broiler chickens. In this study, the phagocytic activity of the heterophil was investigated against the Staphylococcus aureus that commonly infects the chickens. The heterophil is activated during the first lineage of infection (Guriec et al., 2018). It's actively engulfment the bacteria in the circulatory system by forming the cytoplasmic pseudopodia (Mohd et al., 2016). The decrease of the heterophils phagocytic index is suspected due to the shrinkage of mature circulatory heterophil. The systemic inflammation depresses on bone marrow to release the immature heterophil on the circulation. Moreover, it may be caused by the decreasing level of arginine-specific adenosine diphosphate ribosyltransferase (ADP-ribosyltransferase) in the serum that down-regulates the migration, attachment, and phagocytosis of heterophil. Further, the cellular damage of the heterophil impairs the dectin-1-receptor on its surfaces to identify the pathogenic bacteria. The phagocytic activity of the heterophil and monocytes influence the antigen presenting cells that mediated the synthesis of antibody. It is approved by the present findings that indicatedlow antibody against ND, IBD, and AI after vaccination. The highest GMT level only indicated on day 21 in the group treated with high level of aflatoxin $(>101 \mathrm{ppb}<150 \mathrm{ppb})$. It was the compensatory impacts of lymphoid organs depletion during the aflatoxicosis compared to the control. This result was different from the previous study that reported chicken was the most resistant species against the aflatoxin in the poultry industry (Lazona and Diaz, 2006). It is caused by consumption of the aflatoxin during growth that leads the lymphoid tissues atrophy in the broiler chickens. Moreover, vacuolisation in the bursa of fabricius, spleen, and thymus aggravates the synthesis of antibody after vaccination via depression of the lymphocytes in tissue (Chen et al., 2014) and circulatory system (Pandey et al., 2007). 
Table 4. The effects of aflatoxin exposure on the immunohistochemistry of CD3+, CD4+, and CD8+ on day 21 in the lymphoid organ of broiler chickens

\begin{tabular}{|c|c|c|c|c|c|}
\hline \multirow{2}{*}{ Parameters } & \multirow{2}{*}{ Organ } & \multicolumn{4}{|c|}{ Groups } \\
\hline & & $\mathbf{A}$ & B & $\mathbf{C}$ & D \\
\hline \multirow{3}{*}{ CD3+ } & Spleen & $2.40 \pm 0.51^{\mathrm{a}}$ & $1.70 \pm 0.48^{b}$ & $1.40 \pm 0.69^{b}$ & $0.80 \pm 0.42^{\mathrm{c}}$ \\
\hline & Bursa of Fabricius & $2.10 \pm 0.73^{\mathrm{a}}$ & $1.20 \pm 0.91^{\mathrm{b}}$ & $1.00 \pm 0.81^{\mathrm{b}}$ & $0.60 \pm 0.51^{\mathrm{c}}$ \\
\hline & Thymus & $2.40 \pm 0.69^{\mathrm{a}}$ & $1.60 \pm 0.96^{\mathrm{b}}$ & $1.40 \pm 0.96^{\mathrm{b}}$ & $1.00 \pm 0.81^{\mathrm{c}}$ \\
\hline \multirow{3}{*}{ CD4+ } & Spleen & $1.90 \pm 0.56^{\mathrm{a}}$ & $1.50 \pm 0.97^{\mathrm{b}}$ & $1.40 \pm 0.84^{\mathrm{b}}$ & $1.00 \pm 0.66^{\mathrm{c}}$ \\
\hline & Bursa of Fabricius & $2.00 \pm 0.81^{\mathrm{a}}$ & $1.40 \pm 0.84^{\mathrm{b}}$ & $1.20 \pm 0.78^{\mathrm{b}}$ & $0.90 \pm 0.31^{\mathrm{c}}$ \\
\hline & Thymus & $2.00 \pm 0.66^{\mathrm{a}}$ & $1.70 \pm 0.94^{\mathrm{b}}$ & $1.40 \pm 0.69^{\mathrm{b}}$ & $0.80 \pm 0.63^{\mathrm{c}}$ \\
\hline \multirow{3}{*}{ CD8+ } & Spleen & $1.50 \pm 0.52^{\mathrm{a}}$ & $1.00 \pm 0.81^{\mathrm{b}}$ & $1.20 \pm 0.63^{b}$ & $0.80 \pm 0.78^{\mathrm{c}}$ \\
\hline & Bursa of Fabricius & $1.60 \pm 0.51^{\mathrm{a}}$ & $1.30 \pm 0.67^{\mathrm{b}}$ & $1.00 \pm 0.81^{\mathrm{b}}$ & $0.70 \pm 0.67^{\mathrm{c}}$ \\
\hline & Thymus & $1.70 \pm 0.67^{\mathrm{a}}$ & $1.20 \pm 0.78^{\mathrm{b}}$ & $1.20 \pm 0.63^{\mathrm{b}}$ & $0.60 \pm 0.51^{\mathrm{c}}$ \\
\hline
\end{tabular}

$\overline{\mathrm{a}, \mathrm{b}, \mathrm{c}}$ the different superscript on the same row showed significantly different values $(\mathrm{P}<0.05)$.

Table 5. The effects of aflatoxin exposure on the haematological profile of broiler chickens

\begin{tabular}{|c|c|c|c|c|c|c|}
\hline \multirow{2}{*}{\multicolumn{2}{|c|}{ Parameters }} & \multirow{2}{*}{ Day } & \multicolumn{4}{|c|}{ Groups } \\
\hline & & & $\mathbf{A}$ & B & $\mathbf{C}$ & D \\
\hline \multirow{3}{*}{\multicolumn{2}{|c|}{$\begin{array}{l}\text { Red blood cells } \\
\left(\times 10^{6} / \mu \mathrm{L}\right)\end{array}$}} & 7 & $2.25 \pm 0.02^{\mathrm{a}}$ & $2.26 \pm 0.05^{\mathrm{a}}$ & $2.26 \pm 0.08^{\mathrm{a}}$ & $2.24 \pm 0.04^{b}$ \\
\hline & & 14 & $2.39 \pm 0.16^{\mathrm{a}}$ & $2.44 \pm 0.15^{\mathrm{a}}$ & $2.34 \pm 0.08^{\mathrm{a}}$ & $2.31 \pm 0.13^{\mathrm{b}}$ \\
\hline & & 21 & $2.46 \pm 0.03^{\mathrm{a}}$ & $2.41 \pm 0.04^{\mathrm{a}}$ & $2.44 \pm 0.11^{\mathrm{a}}$ & $2.31 \pm 0.10^{\mathrm{b}}$ \\
\hline \multirow{3}{*}{\multicolumn{2}{|c|}{$\begin{array}{l}\text { Packed cells volume } \\
(\%)\end{array}$}} & 7 & $27.30 \pm 1.14^{\mathrm{b}}$ & $27.29 \pm 1.05^{\mathrm{b}}$ & $26.81 \pm 1.24^{b, c}$ & $26.15 \pm 1.08^{c}$ \\
\hline & & 14 & $27.54 \pm 0.64^{\mathrm{b}}$ & $27.39 \pm 0.52^{\mathrm{b}}$ & $26.70 \pm 1.21^{b, c}$ & $26.46 \pm 1.04^{c}$ \\
\hline & & 21 & $27.53 \pm 0.89^{\mathrm{b}}$ & $27.37 \pm 0.83^{b}$ & $27.44 \pm 0.48^{b, c}$ & $27.08 \pm 0.47^{\mathrm{c}}$ \\
\hline \multirow{3}{*}{\multicolumn{2}{|c|}{$\begin{array}{l}\text { Haemoglobin } \\
(g / d L)\end{array}$}} & 7 & $11.10 \pm 0.20^{\mathrm{b}}$ & $10.73 \pm 0.48^{b}$ & $10.48 \pm 0.23^{b, c}$ & $10.37 \pm 0.48^{\mathrm{c}}$ \\
\hline & & 14 & $12.04 \pm 2.58^{\mathrm{b}}$ & $11.28 \pm 0.85^{\mathrm{b}}$ & $10.88 \pm 0.59^{b, c}$ & $11.04 \pm 1.04^{\mathrm{c}}$ \\
\hline & & 21 & $11.24 \pm 0.71^{\mathrm{b}}$ & $11.28 \pm 0.40^{\mathrm{b}}$ & $11.12 \pm 0.84^{b, c}$ & $10.24 \pm 0.17^{\mathrm{c}}$ \\
\hline \multirow{3}{*}{\multicolumn{2}{|c|}{$\begin{array}{l}\text { Mean corpuscular volume } \\
\text { (fL) }\end{array}$}} & 7 & $121.29 \pm 4.15^{\mathrm{a}}$ & $120.46 \pm 5.37^{\mathrm{a}}$ & $118.28 \pm 6.42^{\mathrm{a}}$ & $116.62 \pm 6.28^{\mathrm{a}}$ \\
\hline & & 14 & $115.40 \pm 9.36^{\mathrm{a}}$ & $112.33 \pm 7.64^{\mathrm{a}}$ & $114.25 \pm 7.88^{\mathrm{a}}$ & $115.03 \pm 10.46^{\mathrm{a}}$ \\
\hline & & 21 & $111.55 \pm 4.16^{\mathrm{a}}$ & $113.21 \pm 4.71^{\mathrm{a}}$ & $112.53 \pm 4.87^{\mathrm{a}}$ & $117.36 \pm 7.24^{\mathrm{a}}$ \\
\hline \multirow{3}{*}{\multicolumn{2}{|c|}{$\begin{array}{l}\text { Mean corpuscular haemoglobin } \\
(\mathrm{Pg})\end{array}$}} & 7 & $49.33 \pm 0.95^{\mathrm{a}}$ & $47.37 \pm 2.69^{\mathrm{a}}$ & $46.25 \pm 1.76^{\mathrm{a}}$ & $46.25 \pm 2.12^{\mathrm{a}}$ \\
\hline & & 14 & $50.50 \pm 12.05^{\mathrm{a}}$ & $46.12 \pm 3.04^{\mathrm{a}}$ & $46.50 \pm 2.41^{\mathrm{a}}$ & $47.86 \pm 4.24^{\mathrm{a}}$ \\
\hline & & 21 & $45.53 \pm 2.76^{\mathrm{a}}$ & $46.68 \pm 3.21^{\mathrm{a}}$ & $45.56 \pm 3.36^{\mathrm{a}}$ & $44.37 \pm 2.17^{\mathrm{a}}$ \\
\hline \multirow{3}{*}{\multicolumn{2}{|c|}{$\begin{array}{l}\text { Mean corpuscular haemoglobin } \\
\text { concentration }(\%)\end{array}$}} & 7 & $40.72 \pm 1.95^{\mathrm{a}}$ & $39.32 \pm 1.23^{\mathrm{a}}$ & $39.15 \pm 1.50^{\mathrm{a}}$ & $39.75 \pm 2.53^{\mathrm{a}}$ \\
\hline & & 14 & $43.72 \pm 9.49^{\mathrm{a}}$ & $41.17 \pm 3.10^{\mathrm{a}}$ & $40.90 \pm 3.98^{\mathrm{a}}$ & $41.82 \pm 4.52^{\mathrm{a}}$ \\
\hline & & 21 & $40.86 \pm 2.86^{\mathrm{a}}$ & $41.23 \pm 2.29^{\mathrm{a}}$ & $40.55 \pm 3.38^{\mathrm{a}}$ & $37.84 \pm 0.78^{\mathrm{a}}$ \\
\hline \multirow{3}{*}{\multicolumn{2}{|c|}{$\begin{array}{l}\text { White blood cells } \\
\left(\times 10^{3} / \mu \mathrm{L}\right)\end{array}$}} & 7 & $21.22 \pm 1.92^{\mathrm{a}}$ & $21.42 \pm 1.63^{\mathrm{a}}$ & $21.41 \pm 2.43^{\mathrm{a}}$ & $20.92 \pm 1.01^{b}$ \\
\hline & & 14 & $21.71 \pm 0.98^{\mathrm{a}}$ & $21.75 \pm 1.28^{\mathrm{a}}$ & $20.53 \pm 0.72^{\mathrm{a}}$ & $19.61 \pm 0.40^{\mathrm{b}}$ \\
\hline & & 21 & $20.82 \pm 0.99^{\mathrm{a}}$ & $21.02 \pm 0.74^{\mathrm{a}}$ & $18.98 \pm 1.32^{\mathrm{a}}$ & $18.29 \pm 1.24^{\mathrm{b}}$ \\
\hline \multirow{15}{*}{ 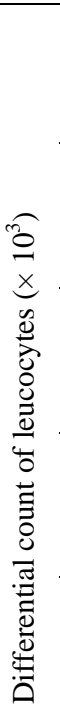 } & \multirow{3}{*}{ Heterophils } & 7 & $5.62 \pm 0.58^{\mathrm{a}}$ & $5.44 \pm 1.01^{\mathrm{a}}$ & $5.86 \pm 0.72^{\mathrm{a}}$ & $6.06 \pm 0.31^{\mathrm{a}}$ \\
\hline & & 14 & $5.69 \pm 0.50^{\mathrm{a}}$ & $6.00 \pm 0.42^{\mathrm{a}}$ & $5.62 \pm 0.74^{\mathrm{a}}$ & $5.60 \pm 0.40^{\mathrm{a}}$ \\
\hline & & 21 & $5.45 \pm 0.55^{\mathrm{a}}$ & $5.56 \pm 0.28^{\mathrm{a}}$ & $5.12 \pm 0.52^{\mathrm{a}}$ & $4.90 \pm 0.73^{\mathrm{a}}$ \\
\hline & \multirow{3}{*}{ Lymphocytes } & 7 & $13.21 \pm 0.12^{\mathrm{b}}$ & $13.63 \pm 0.11^{b}$ & $12.08 \pm 0.21^{\mathrm{c}}$ & $11.52 \pm 0.16^{\mathrm{c}}$ \\
\hline & & 14 & $13.35 \pm 0.12^{\mathrm{b}}$ & $13.08 \pm 0.07^{\mathrm{b}}$ & $12.50 \pm 0.10^{c}$ & $11.06 \pm 0.12^{\mathrm{c}}$ \\
\hline & & 21 & $12.42 \pm 0.06^{\mathrm{b}}$ & $12.94 \pm 0.08^{\mathrm{b}}$ & $11.13 \pm 0.09^{c}$ & $0.97 \pm 0.06^{\mathrm{c}}$ \\
\hline & \multirow{3}{*}{ Monocytes } & 7 & $1.77 \pm 0.71^{\mathrm{a}}$ & $1.94 \pm 1.08^{\mathrm{a}}$ & $2.66 \pm 0.41^{\mathrm{a}}$ & $2.45 \pm 0.83^{b}$ \\
\hline & & 14 & $1.75 \pm 0.48^{\mathrm{a}}$ & $2.28 \pm 0.42^{\mathrm{a}}$ & $1.85 \pm 0.63^{\mathrm{a}}$ & $2.33 \pm 0.64^{\mathrm{b}}$ \\
\hline & & 21 & $1.75 \pm 0.24^{\mathrm{a}}$ & $1.79 \pm 0.60^{\mathrm{a}}$ & $1.79 \pm 0.93^{\mathrm{a}}$ & $2.42 \pm 0.78^{\mathrm{b}}$ \\
\hline & \multirow{3}{*}{ Eosinophils } & 7 & $0.54 \pm 0.49^{\mathrm{a}}$ & $0.31 \pm 0.22^{b}$ & $0.57 \pm 0.56^{\mathrm{a}}$ & $0.70 \pm 0.44^{b}$ \\
\hline & & 14 & $0.64 \pm 0.57^{\mathrm{a}}$ & $0.28 \pm 0.25^{\mathrm{b}}$ & $0.45 \pm 0.38^{\mathrm{a}}$ & $0.47 \pm 0.59^{b}$ \\
\hline & & 21 & $0.86 \pm 0.40^{\mathrm{a}}$ & $0.54 \pm 0.29^{b}$ & $0.78 \pm 0.5^{\mathrm{a}}$ & $0.92 \pm 0.38^{\mathrm{b}}$ \\
\hline & \multirow{3}{*}{ Basophils } & 7 & $0.06 \pm 0.13^{\mathrm{a}}$ & $0.08 \pm 0.25^{\mathrm{a}}$ & $0.22 \pm 0.27^{\mathrm{a}}$ & $0.17 \pm 0.28^{\mathrm{a}}$ \\
\hline & & 14 & $0.26 \pm 0.27^{\mathrm{a}}$ & $0.08 \pm 0.15^{\mathrm{a}}$ & $0.10 \pm 0.14^{\mathrm{a}}$ & $0.13 \pm 0.25^{\mathrm{a}}$ \\
\hline & & 21 & $0.32 \pm 0.35^{\mathrm{a}}$ & $0.16 \pm 0.27^{\mathrm{a}}$ & $0.14 \pm 0.32^{\mathrm{a}}$ & $0.29 \pm 0.51^{\mathrm{a}}$ \\
\hline
\end{tabular}

$\overline{a, b, c}$ the different superscript on the same row showed significantly different values $(\mathrm{P}<0.05)$. 
Table 6. The effects of aflatoxin exposure on the heterophil phagocytic activity, average phagocytic bacteria, and phagocytic index against Staphylococcus aureus bacteria in broiler chicken

\begin{tabular}{|c|c|c|c|c|c|}
\hline \multirow{2}{*}{ Parameters } & \multirow{2}{*}{ Day } & \multicolumn{4}{|c|}{ Groups } \\
\hline & & $\mathbf{A}$ & B & $\mathbf{C}$ & D \\
\hline \multirow{3}{*}{$\begin{array}{l}\text { Heterophil phagocytic activity } \\
(\%)\end{array}$} & 7 & $50.10 \pm 0.05^{\mathrm{a}}$ & $0.48 \pm 0.05^{b}$ & $0.46 \pm 0.03^{b}$ & $0.40 \pm 0.04^{b}$ \\
\hline & 14 & $48.50 \pm 0.05^{\mathrm{a}}$ & $0.48 \pm 0.06^{\mathrm{b}}$ & $0.46 \pm 0.06^{\mathrm{b}}$ & $0.39 \pm 0.05^{\mathrm{b}}$ \\
\hline & 21 & $51.00 \pm 0.04^{\mathrm{a}}$ & $0.47 \pm 0.04^{b}$ & $0.41 \pm 0.03^{b}$ & $0.39 \pm 0.04^{b}$ \\
\hline \multirow{2}{*}{$\begin{array}{l}\text { Average phagocytic bacteria } \\
\text { (cells) }\end{array}$} & 7 & $1.77 \pm 0.33^{\mathrm{a}}$ & $1.90 \pm 0.38^{b}$ & $1.57 \pm 0.22^{b}$ & $1.50 \pm 0.29^{b}$ \\
\hline & 14 & $1.86 \pm 0.23^{\mathrm{a}}$ & $1.89 \pm 0.25^{\mathrm{b}}$ & $1.71 \pm 0.16^{\mathrm{b}}$ & $1.59 \pm 0.19^{b}$ \\
\hline \multirow{2}{*}{$\begin{array}{l}\text { Phagocytic index } \\
(\%)\end{array}$} & 14 & $90.59 \pm 17.10^{\mathrm{a}}$ & $91.92 \pm 17.82^{\mathrm{a}}$ & $79.93 \pm 14.28^{b}$ & $62.11 \pm 9.83^{c}$ \\
\hline & 21 & $92.77 \pm 16.36^{\mathrm{a}}$ & $85.65 \pm 20.25^{\mathrm{a}}$ & $59.83 \pm 9.86^{\mathrm{b}}$ & $46.34 \pm 8.16^{c}$ \\
\hline
\end{tabular}

$\overline{\mathrm{a}, \mathrm{b}, \mathrm{c}}$ the different superscript on the same row showed significantly different values $(\mathrm{P}<0.05)$

Aflatoxin was undetected as the residue on the broiler chicken organs in group $\mathrm{A}, \mathrm{B}$, and $\mathrm{C}$ during the observation periods. It is detected on the liver ( 0.10 to 0.12 $\mathrm{ppb}$ ), skin (0.02 to $0.09 \mathrm{ppb}$ ), and muscle (0.03 to 0.10 ppb) only in birds treated with high level of aflatoxin (> $101 \mathrm{ppb}<150 \mathrm{ppb})$ on day 21 . The liver becomes the organ with the highest aflatoxin residue because of its activity to detoxify and metabolise the toxins. The hypodermis consists of the adipose tissue arranged by adipocytes that potential as the storage of the energy and metabolite products such as toxin and antibiotics and also it is similar to muscle tissues (Sinique et al., 2017). The chicken's breast muscle is the prominent part of the poultry's final product with a high economic value and the highest of human consumption rate. The monitoring of aflatoxin contamination on the chicken stuff is necessary to be conducted routinely in the poultry industry. It is because of the aflatoxin residue in the poultry's final products also found in the edible tissue such as muscle and liver that is commonly consumed by a human (DiazZaragosa et al., 2014). In the long period of consumption of aflatoxin promotes the carcinogenesis and mutagenesis even at a low level (Adam et al., 2017).

\section{CONCLUSION}

The varying doses of aflatoxin in the chicken feeds caused the problems with different severity and impacts. High level of aflatoxin $(>101<150 \mathrm{ppb})$ was significantly adverse to the physical performance (body weight, FI, FCR, the relative weight of the organ) and laboratory indicators (histopathological changing, immuneexpression of $\mathrm{CD} 3+$ and $\mathrm{CD} 4+$, promote the nonregenerative anaemia, decrease the role of leucocytes, heterophil phagocytic activity, phagocytic index, depress the synthesis of antibody), and also increasd risk of residue in the poultry's final products.

\section{DECLARATIONS}

\section{Acknowledgements}

This study is partially funded by M. J. Ahmed Farm with grant number [07.07.Ah.2017]. All the laboratory technicians form the integrated laboratory, university of Muhammadiyah Sidoarjo, faculty of veterinary medicine, university of Wijaya Kusuma Surabaya, and disease investigation Centre Yogyakarta, were acknowledged for their assistant during this study.

\section{Author's contribution}

Kurniasih and Yos Adi Prakoso participated in design, experimental procedure, writing, revised, and reviewing the manuscript.

\section{Competing interests}

The authors have declared that no competing interest exists.

\section{Consent to publish}

The authors guarantee that this work has not been published elsewhere and that any person named as a coauthor of this work is aware of the fact and has agreed to be so named.

\section{REFERENCES}

Adam MAA, Tabana YM, Musa KB and Sandai DA (2017). Effects on different mycotoxins on humans, cell genome and their involvement in cancer (review). Oncology Reports, 37 (3): 1321-1336. DOI: 10.3892/or.2017.5424.

An Y, Shi X, Tang X, Wang Y, Shen F, Zhang Q, Wang C, Jiang M, Liu M and Yu L (2017). Aflatoxin B1 induces reactive 
oxygen species - mediated autophagy and external trap formation in macrophages. Frointers in Cellular and Infection Microbiology, 7 (53): 1-16. DOI: 10.3389/fcimb.2017.00053.

Baptista AS, Abdalla AL, Aguiar CL, Baptista AAS, Micheluchi D, Zampronio AC, Pires DS, Gloria EM, CaloriDomingues MA, Walder JMM, et al. (2008). Utilization of diets amanded with yeast and amino acids for the control of aflatoxicosis. World Journal of Microbiology and Biotechnology, 24 (11): 2547-2554. DOI: 10.1007/s11274008-9776-5.

Bintvihok A and Kositcharoenkul S (2006). Effect of dietary calcium propionate on the performance, hepatic enzyme activities and aflatoxin residues in broiler fed a diet containing low levels of aflatoxin B1. Toxicon, 47 (1): 4146. DOI: 10.1016/j.toxicon.2005.09.009.

Chen K, Fang J, Peng X, Cui H, Chen J, Wang F, Chen Z, Zuo Z, Deng J, Lai W and Zhou Y (2014). Effects of selenium supplementation on aflatoxin B1 induced histopathological lesion and apoptosis in bursa of Fabricius in broilers. Food and Chemical Toxicology, 74: 91-97. DOI: 10.1016/j.fct.2014.09.003.

Colakoglu F and Donmez HH (2012). Effects of aflatoxin on liver and protective effectiveness of esterified glucomannan in merino rams. The Scientific World Journal, 2012 (462925): 1-5. DOI: 10.1100/2012/462925.

Denli M, Blandon JC, Guynot ME, Salado S and Perez JF (2009). Effects of dietary afladetox on performance, serum biochemistry, histopathological changes, and aflatoxin residues in broiler exposed to aflatoxin B1. Poultry Science, 88 (7): 1444-1451. DOI: 10.3382/ps.2008-00341.

Diaz-Zaragoza M, Carvajal-Moreno M, Mendez-Ramirez I, Chilpa-Galvan NC, Avila-Gonzalez E and Flores-Ortiz CM (2014). Aflatoxins, hydroxylated metabolites, and aflatoxicol from breast muscle of laying hens. Poultry Science, 93 (12): 3152-3162. DOI: 10.3382/ps.201404240.

Donmez N, Donmez HH, Keskin E and Kisadere I (2012). Effects of aflatoxin in some haematological parameters and protective effectiveness of esterified glucomannan in Merino Rams. The Scientific World Journal, 2012 (342468): 1-4. DOI: 10.1100/2012/342468.

Guo C, Sun L, Chen X and Zhang D (2013). Oxidative stress, mitochondrial damage and neurodegenerative diseases. Neural Regeneration Research, 8 (21): 2003-2014. DOI: 10.3969/j.issn.1673-5374.2013.21.009.

Guriec N, Bussy F, Gouin C, Mathiaud O, Quero B, Goff ML and Collen PN (2018). Ulvan activated chickens heterophils and monocytes through toll-like receptor 2 and toll-like receptor 4. Frontiers in Immunology, 9 (2725): 119. DOI: $10.3389 \% 2$ Ffimmu.2018.02725.

Kamala A, Shirima C, Jani B, Bakari M, Sillo H, Rusibamayila N, De Saeger S, Kimanya M, Gong YY, Simba A, et al. (2018). Outbreak of an acute aflatoxicosis in Tanzania during 2016. World Mycotoxin Journal, 11 (3): 311-320. DOI: 10.3920/WMJ2018.2344.

Kempashi J, Kannan T, Basha SH, Raja A and Ramesh G (2017). Flow cytometric analysis of $\mathrm{T}$ cell subset in bursa of fabricius in broiler chicken (Gallus domesticus),"
International Journal of Current Microbiology and Applied Sciences, 6 (2): $1534-1539 . \quad$ DOI: 10.20546/ijcmas.2017.602.171.

Kim J, Park SH, Do KH, Kim D and Moon Y (2016). Interference with mutagenic aflatoxin B1-induced checkpoints through antagonistic action of ochratoxin A in intestinal cancer cells: a molecular explanation on potential risk of crosstalk between carcinogens. Oncotarget, 7 (26): 39627-39639. DOI: 10.18632\%2Foncotarget.8914.

Liang N, Wang F, Peng X, Fang J, Cui H, Chen Z, Lai W, Zhou $\mathrm{H}$ and Geng $\mathrm{Y}$ (2015). Effect of sodium selenite on pathological changes and renal functions in broilers fed a diet containing aflatoxin B1. International Journal of Experimental Research and Public Health, 12 (9): 1119611208. DOI: 10.3390/ijerph120911196.

Lozano MC and Diaz GJ (2006). Microsomal and cytosolic biotransformation of aflatoxin B1 in four poultry species. British Poultry Science, 47 (6): 734-741. DOI: 10.1080/00071660601084390.

Mahfouz ME and Sherif AH (2015). A multiparameter investigation into adverse effects of aflatoxin on Oreochromis niloticus health status. The Journal of Basic and Applied Zoology, 71: 48-59. DOI: 10.1016/j.jobaz.2015.04.008.

Manafi M, Hedayati M and Yari M (2014). Effectiveness of rosemary (Rosmarinus officinalis L.) essence on performance and immune parameters of broilers during aflatoxicosis. Advances in Life Sciences, 4 (3): 166-173. DOI: 10.5923/j.als.20140403.12.

Matur E, Ergul E, Akyazi I, Eraslan E and Cirakli ZT (2010). The effects of Saccharomyces cerevisiae extract on the weight of some organs, liver, and pancreatic digestive enzyme activity in breeder hens fed diets contaminated with aflatoxins. Poultry Science, 89 (10): 2213-2220. DOI: 10.3382/ps.2010-00821.

Mohd KI, Mrigesh M, Singh B and Singh I (2016). Ultrastructural study on the granulocytes of Uttara fowl (Gallus domesticus). Veterinary World, 9 (3): 320-325. DOI: 10.14202\%2Fvetworld.2016.320-325.

Morrison DM, Ledoux DR, Chester LFB and Samuels CAN (2017). A limited survey of aflatoxins in poultry feed and feed ingredients in Guyana. Veterinary Sciences, 4 (4): 60. DOI: $10.3390 \% 2 F v e t s c i 4040060$.

Mughal MJ, Peng X, Kamboh AA, Zhou Y and Fang J (2017). Aflatoxin B1 induced systemic toxicity in poultry and rescue effects of selenium and zinc. Biological Trace Element Research, 178 (2): 292-300. DOI: 10.1007/s12011-016-0923-9.

Nagel A, Mobs C, Raifer H, Wiendl H, Hertl M and Eming R (2014). CD3-positive B cells: a storage-dependent phenomenon. PLoS ONE, 9 (10): e110138. DOI: 10.1371/journal.pone.0110138.

Pandey I and Chauhan SS (2007). Studies on production performance and residues in tissues and eggs of layer chickens fed on diets with various concentration of aflatoxin AFB1. British Poultry Science, 48 (6): 713-723. DOI: 10.1080/00071660701713534.

Peng X, Bai S, Ding X, Zeng Q, Zhang K and Fang J (2015). Pathological change in the immune organs of broiler 
chickens fed on corn naturally contaminated with aflatoxin B1 and B2. Avian Pathology, (3): 192-199. DOI: 10.1080/03079457.2015.1023179.

Prakoso YA, Puspitasari, Rini CS, Aliviameita A, Salasia SIO, Kurniasih, Ikram AFD, Walalangi B, Utama KP, Al Huda MF and Su'udiyah NA (2018). The role of Sauropus androgynus (L.) Merr leaf powder in the broiler chickens fed a diet naturally contaminated with aflatoxin. Journal of Toxicology, 2018 (2069073): 1-18. DOI: 10.1155/2018/2069073.

Qureshi H, Hamis SS, Ali SS, Anwar J, Siddiqui AA and Khan NA (2015). Cytotoxic effects of aflatoxin B1 on human brain microvascular endothelial cells of the blood-brain barrier. Medical Mycology, 53 (4): 409-416. DOI: 10.1093/mmy/myv010.

Sarma UP, Bhetaria PJ, Devi P and Varma A (2017). Aflatoxins: implications on health. Indian Journal of Clinical Biochemistry, 32 (2): 124-133. DOI: $10.1007 \% 2 F s 12291-$ 017-0649-2.

Sinique AR, Macuamule CL and Anjos FRD (2017). Aflatoxin B1 contamination in chicken livers and gizzards from industrial and small abbatoirs, measured by ELISA technique in Maputo, Mozambique. İnternational Journal of Environmental Research and Public Health, 14 (9): 951. DOI: 10.3390/ijerph14090951.

Sornplang E, Leelavatcharamas V and Soikum C (2015). Heterophil phagocytic activity stimulated by Lactobacillus salivarius L61 and L55 supplementation in broilers with Salmonella infection. Asian-Australasian Journal of Animal Sciences, 28 (11): 1657-1661. DOI: 10.5713/ajas.15.0359.

Tessari ENC, Kobashigawa E, Cardoso ALSP, Ledoux DR, Rottinghaus GE and Oliveira CA (2010). Effects of aflatoxin B1 and fumonisin B1 on blood biochemical parameters in broilers. Toxins, 2 (4): 453-460. DOI: 10.3390/toxins 2040453 .

Tokonami N, Morla L, Centeno G, Mordasini D, Ramakrishnan SK, Nikolaeva S, Wagner CA, Bonny O, Houillier P, Doucet A and Firsov D (2013). $\alpha$-Ketoglutarate regulates acid-base balance through an intrarenal paracrine mechanism. The Journal of Clinical Investigation, 123 (7): 3166-3171. DOI: 10.1172/JCI67562.

Wogan GN, Kensler TW and Groopman JD (2012). Present and future directions of translational research on aflatoxin and hepatocellular carcinoma: a review. Food Additive \& Contaminant, $29 \quad$ (2): 249-257. DOI: 10.1080/19440049.2011.563370.

Yaman T, Yener Z and Celik I (2016). Histopathological and biochemical incestigations of protective role of honey in rats with experimental aflatoxicosis. BMC Complementary \& Alternative Medicine, 16 (232): 1-11. DOI: 10.1186/s12906-016-1217-7.

Yang S, Zhao Z, Zhang A, Jia F, Song M, Huang Z, Fu J, Li G and Lin S (2018). Proteomics analysis of chicken peripheral blood lymphocyte in Taishan Pinus massoniana pollen polysaccharide regulation. PLoS ONE, 13 (11): e0208314. DOI: 10.1371/journal.pone.0208314.

Zuidhof MJ, Schneider BL, Carney VL, Korver DR and Robinson FE (2014). Growth, efficiency, and yield of commercial broilers from 1957, 1978, and 2005. Poultry Science, 93 (12): 2970-2982. DOI: 10.3382/ps.201404291. 